\title{
A mídia, o sagrado e as imposturas da imagem: implicações semióticas das charges de Maomé*
}

\section{RESUMO}

Este trabalho dedica-se a analisar as implicações semióticas da publicação das charges de Maomé em um jornal dinamarquês em setembro de 2005. Além de descrever os impactos da publicação, que se estenderam até o ano de 2006, são consideradas aqui as dimensões políticas e religiosas da imagem, destacando também aspectos de linguagem próprios da charge. Tomando como aporte teórico os estudos empreendidos pela Escola de TártuMoscou, entre outras perspectivas, o artigo se debruça para estudar uma das charges, relacionando-a às posturas iconoclastas próprias da parte Protestante do Ocidente. Assim, a charge é compreendida como um dos elementos simbólicos demarcadores das tensões culturais entre Ocidente Cristão e Oriente Islâmico.

\section{PALAVRAS-CHAVE}

Maomé

charge

imagem

\section{ABSTRACT}

This article intends to analyze the semiotic implications of Mohamed's cartoons in a Danish newspaper in September of 2005. Besides describing the impacts of the publication, which reached the year 2006, this paper considers the political and religious dimensions of the images, highlighting language features of the cartoons. The images are studied through the theoretical frame of the Tartu-Moscow semiotic school, among other perspectives, relating them to the iconoclast position of the Protestants in the western culture. Thus, the cartoons are taken as symbolic elements that signalize cultural tensions between East and West.

\section{KEY WORDS}

Mohamed

cartoon

image

\section{Alberto Klein}

Professor do Departamento de Comunicação da UEL/PR/BR

betoklein@yahoo.com.br

\section{Rozinaldo Antônio Miani}

Professor do Departamento de Comunicação da UEL/PR/BR ramiani@uol.com.br

\section{Introdução}

Quando Flemming Rose, editor de cultura do jornal dinamarquês Jyllands-Posten, decidiu convidar cartunistas a enviarem charges sobre Maomé para o jornal, certamente não calculava a dimensão que a repercussão de tais ilustrações tomaria. As charges, num total de 12, foram publicadas pela primeira vez em 30 de setembro de 2005 no referido jornal e depois reproduzidas ao longo dos 5 meses seguintes por diversos jornais europeus como forma de solidariedade e reafirmação de uma liberdade de imprensa reivindicada. Dentre as 12 charges, dez retratam a figura de Maomé, prática proibida pela tradição islâmica.

De acordo com a jornalista Isis Almeida, do site Opinião e Notícia, a inspiração para a produção das charges surgiu em 2005,

[...] quando o editor de cultura do Jyllands-Posten, Flemming Rose, ficou sabendo que o escritor dinamarquês Kåre Bluitgen, que havia escrito uma biografia de Maomé para crianças, não conseguia encontrar ilustradores que concordassem em fazer desenhos do profeta. Irritado com a auto-censura que tomou conta dos dinamarqueses depois do assassinato do cineasta holandês Theo Van Gogh por um radical muçulmano, Rose teve a idéia de convocar cartunistas para fazer os desenhos. Van Gogh havia feito um filme criticando o tratamento das mulheres no Islã (ALMEIDA, 2006).

As charges foram enviadas e publicadas sob pretexto do exercício de liberdade de imprensa. A repercussão não foi imediata, porém, alguns meses depois da publicação pelo jornal dinamarquês e republicação em diversos outros jornais, a TV árabe Al-Jazeera produziu uma reportagem sobre o caso e, a partir de então, a atenção e a ira dos muçulmanos foram despertadas.

Dentre as charges produzidas, duas causaram revolta generalizada. A mais polêmica delas, produzida por Kurt Westergård, mostra o profeta Maomé com um turbante na forma de uma bomba e prestes a explodir; a associação do profeta ao terrorismo soou como uma provocação aos muçulmanos, além de sugerir que a base fundamental da religião é terrorista. A outra charge fartamente criticada foi a que mostra Maomé pedindo aos terroristas islâmicos que parem com os atentados, porque já não há virgens suficientes no Paraíso.

Diante da inconformidade pela ofensa, a menor das exigências foi uma retratação e um pedido de desculpas pela "provocação européia" contra o sentimento islâmico. No entanto, mesmo os pedidos formais de desculpas vindos de várias partes não foram suficientes para evi- 
tar uma verdadeira onda de protestos, ataques virtuais e boicotes no mundo islâmico e na Europa.

O mês de fevereiro de 2006 foi marcado por inúmeros episódios que indicaram a gravidade da questão política e diplomática que se estabeleceu em razão da publicação das charges. A representação da União Européia na Faixa de Gaza foi cercada por manifestantes palestinos armados dos grupos Jihad e Brigada Al Aksa que exigiram o fechamento do referido escritório; a Arábia Saudita, a Líbia e o Kuwait fecharam suas representações diplomáticas na Dinamarca; em repúdio às charges, o Irã anunciou o fim dos laços comerciais com a Dinamarca; manifestantes sírios atearam fogo nas embaixadas da Dinamarca e da Noruega, em Damasco; mulheres em protesto queimaram bandeiras da Dinamarca em Sanaa, capital do Iêmen, e pediram boicote a produtos do país; centenas de estudantes saíram em passeata pelas ruas das cidades paquistanesas de Lahore e Multan queimando bandeiras e retratos do primeiro-ministro da $\mathrm{Di}$ namarca; no Irã, dezenas de pessoas apedrejaram e atiraram coquetéis molotov contra a embaixada da Áustria; manifestantes atiraram ovos no escudo dinamarquês na entrada da embaixada do país na Indonésia onde, ain$\mathrm{da}$, foi registrado um incidente envolvendo policiais e um grupo de manifestantes que pretendia atacar os consulados dos Estados Unidos e da Dinamarca. Essas foram apenas algumas das ações registradas pela imprensa internacional como reação ao desrespeito contra a autoridade religiosa islâmica.

Algumas manifestações tomaram ares de violência extrema e resultaram, inclusive, em mortes. Foi o caso das manifestações ocorridas na cidade de Maiduguri, na Nigéria, onde igrejas foram incendiadas e cristãos atacados em um protesto de muçulmanos que resultou na morte de pelo menos 15 pessoas. Além desse episódio, foram registradas ainda, na época, a morte de 4 pessoas no Afeganistão e uma no Líbano em atos contra as caricaturas de Maomé.

Outra conseqüência da publicação das charges de Maomé incidiu sobre os próprios jornalistas ou veículos de imprensa que divulgaram as caricaturas. $\mathrm{Na}$ época dos protestos, os escritórios do Jyllands-Posten chegaram a ser desocupados por causa de uma ameaça de bomba. O egípcio Raymond Lakah, dono do jornal francês France Soir, demitiu Jacques Lefranc, diretor de redação do jornal, por ter republicado as imagens de Maomé. Mikhail Smirnov, dono do semanário Nash Region que circulava na cidade de Vologda no noroeste da Rússia, decidiu encerrar as atividades do jornal depois de ter sido aberto um processo contra o semanário por parte da procuradoria regional. Ainda na Rússia, o jornal Gorodskie Vesti da cidade de Volgogrado também foi encerrado, por determinação das autoridades municipais, por ter publicado uma charge de conteúdo religioso ofensivo, fazendo referência ao episódio das charges de Maomé. Na Arábia Saudita, as autoridades também ordenaram o encerramento do semanário Shams, três semanas após este ter republicado três dos desenhos de
Maomé originalmente publicado no Jyllands-Posten.

Ainda sobre esse aspecto, faz-se necessário registrar o episódio da prisão de dois jornalistas, Jihad Momani, ex-redator-chefe do semanário Shihan, e Hajem Jalidi, editor do semanário Al-Mihwar, que haviam sido condenados a dois meses de prisão por um tribunal da Jordânia por terem republicado as charges de Maomé. Os jornalistas foram postos em liberdade após o pagamento de fiança, mas ainda esperam o julgamento final.

As ameaças e protestos contra as charges de Maomé também atingiram o mundo virtual. De acordo com o site Zone- $\mathrm{H}^{1}$, que monitora as atividades de criminosos virtuais, cerca de mil web sites dinamarqueses foram atacados por hackers islâmicos em protesto contra as polêmicas charges; ainda de acordo com o referido site, os grupos envolvidos nestas ações vinham da Turquia, Arábia Saudita, Omã e Indonésia. Também foram registrados ataques em sites judaicos, como, por exemplo, no Hagalil.com, portal judaico na Alemanha.

Registramos, ainda, como última grande conseqüência da publicação das charges de Maomé, o boicote feito principalmente a produtos dinamarqueses. O exemplo mais significativo foi o da empresa dinamarquesa-sueca de laticínios Arla Foods que afirmou, à época, que suas vendas no Oriente Médio baixaram a zero e que, em razão da queda na demanda, foi obrigada a demitir vários funcionários.

Diante da avalanche de repercussões e conseqüências, há que se questionar se, de fato, imperou uma ingenuidade por parte do editor do jornal dinamarquês em publicar as charges de Maomé, como se pretendeu justificar. Contrariamente a esta alegação, concordamos com a opinião de Mário Maestri e Marconi de Matos ao afirmarem que:

A publicação, em 30 de setembro de 2005, das doze charges com a imagem do profeta Maomé, foi iniciativa política consciente do Jyllands-Posten, principal jornal dinamarquês, de clara orientação direitista, contra a comunidade islâmica do país. Com outras publicações direitistas dinamarquesas, o jornal participa de ativa campanha xenofóbica, mais ou menos aberta, contra a comunidade de confissão muçulmana, que é sistematicamente acusada de ser refratária aos princípios e práticas democráticas do Ocidente (MAESTRI; MATOS, 2006).

A justificação por tal atitude residiu no suposto direito à liberdade de expressão reivindicada pelo jornal dinamarquês que, de certa forma, acabou por desqualificar a base cultural do mundo islâmico, alicerçada pela religião. No entanto, o conflito entre o princípio sagrado religioso do Islã e o princípio político da liberdade de expressão ocidental deve ser discutido sob a ótica do relativismo cultural. Vale lembrar que o próprio mundo ocidental foi, outrora, governado por valores morais impostos pela Igreja durante vários séculos. 
Sobre a questão da liberdade de expressão, e o necessário bom senso em relação ao relativismo cultural e ético, Ricardo Diaz afirma que:

A abordagem específica da liberdade de expressão está intimamente ligada ao contexto histórico e social de determinada sociedade ou cultura. Os processos de transformações das liberdades civis não aconteceram de maneira natural e progressiva, mas sim de modo dialético, contraditório e fruto do conflito de formas opostas de pensamento que surgiram ao longo dos anos. [...] Os meios de comunicação devem sempre exercer sua liberdade de expressão e analisar os fatos a partir de um espírito crítico e científico, acompanhando de perto os desdobramentos geopolíticos do mundo e combater as agressões aos direitos humanos, mas deve agir com responsabilidade, ética e bom senso (DIAZ, 2006).

Enfim, a afronta aos princípios ético-religiosos dos muçulmanos foi materializada em reação política internacional e as charges de Maomé foram, apenas, o estopim de uma hostilidade que vem sendo alimentada há anos, travestida de uma idéia equivocada de "choque de civilizações". Neste sentido, não podemos desconsiderar a postura imperialista européia em relação a quaisquer outras culturas e, a esse respeito, fazemos côro com as idéias do professor Martin Jaques, do Instituto de Pesquisa da Ásia, vinculado à Universidade Nacional de Cingapura, que foram assim sistematizadas por Lejeune Mato Grosso de Carvalho:

- A Europa nunca se preocupou muito com efeitos de suas atitudes pelo simples fato de que nos últimos 200 anos sua ação foi sempre imperialista, de ocupação de diversos países do mundo. Isso significa que nunca ela levou em conta sensibilidades de pessoas, povos e países, por mais sagradas que elas possam ser;

- Muito ao contrário, os países imperialistas europeus acabaram impondo a muitos países e povos, a sua cultura, sua língua, seus costumes e até sua religião cristã. Isso mostra a grande hipocrisia quando hoje, os mesmos europeus, se queixam das minorias étnicas que vivem no continente, sejam elas muçulmanas ou não;

- O autor afirma que a Europa precisa superar as suas atitudes arrogantes e de desdém contra outros povos e países, deixar de parecer superior, especialmente achando que sua cultura e sua civilização são melhores que as outras;

- A decisão de publicar as charges se assenta muito mais na concepção de desprezo que os editores e a elite dinamarquesa tem pelos muçulmanos e sua religião, do que pelo seu "amor" às liberdades de expressão;

- Essas atitudes nada mais são do que uma combi- nação que mistura eurocentrismo, velhas atitudes coloniais, supremacia, racismo, provincianismo e pura ignorância (CARVALHO, 2006).

\section{Charge: dissertação e poder de mobilização}

O episódio das charges de Maomé só fez reforçar a conviç̧ão do poder persuasivo e mobilizador da charge. Essa questão foi largamente abordada por Rozinaldo Miani para quem "a charge é uma representação humorística de caráter eminentemente político que satiriza um fato ou indivíduo específicos; ela é a revelação e defesa de uma idéia, portanto de natureza dissertativa, traduzida a partir dos recursos e da técnica da ilustração" (MIANI, 2005, p. 25).

Em relação às charges de Maomé, a natureza dissertativa da charge pode ser verificada de maneira bastante significativa se convertendo cada uma delas em uma espécie de "editorial gráfico", imbuídas de concepções e valores claramente identificáveis.

Para além de sua condição de eficiente estratégia persuasiva, deve-se reconhecer também como função social da charge a sua capacidade de mobilização. A esse respeito admitimos que:

[...] a charge pretende não somente dissertar sobre um determinado assunto, mas levar o seu receptor ao convencimento, objetivando inclusive uma mudança de consciência e de atitude. A charge se converte, por influência da instituição que a produz e dissemina, num verdadeiro discurso de convencimento (MIANI, 2005, p. 33).

A convicção sobre o poder persuasivo e mobilizador da charge é comungado não apenas por estudiosos do assunto, mas também pelos próprios chargistas. José Alberto Lovetro (mais conhecido no meio artístico como Jal), um dos organizadores e promotores do famoso prêmio HQMix, reconhece o potencial questionador das charges, atribuindo ao humor presente em tais ilustrações uma condição revolucionária. Afirma o chargista:

O poder da charge cria e destrói ícones com seu simbolismo exacerbado. A função do humor é questionar o poder a todo momento. Por isso é altamente revolucionário. Quando Chaplin fazia de bobo um guarda de rua, em seus filmes, sabia que ridicularizar o poder descontrai o ser humano e o faz rir. Portanto o humor veio para contrapor regras sociais, questioná-las e descontrair (LOVETRO, 2007).

Mediante o reconhecimento do poder transgressor da charge, por seu humor, ou como preferiu afirmar Umberto Eco (1989: 19) que o humor "mina la ley", desconsiderá-lo, por ingenuidade ou negligência, pode proporcionar efeitos colaterais indesejáveis, quanto mais se a intencionalidade configurar uma provocação desmedida. Nesse sentido, concordamos com a análise sobre o 
significado das charges de Maomé apresentada por Roberto Baronas, ao afirmar que:

As charges e as caricaturas de Maomé veiculadas pelos jornais europeus associam humor a uma agressividade simbólica, zombando não de um simples indivíduo, por mais relevante que seja, mas de um ícone religioso que representa o conjunto dos muçulmanos. Longe de serem desenhos inofensivos esses textos são derrisões, uma violência simbólica: um misto de ironia e agressividade verbo-visual que no Ocidente foge das sanções legais por provocar o riso. As charges e as caricaturas explicitam o "outro" temido, como o exato oposto de nós, que deve, portanto, ser rejeitado (BARONAS, 2007).

Diante de tais considerações, mais do que uma manifestação de desprezo pelos princípios religiosos dos muçulmanos, o que se pode observar no episódio das charges de Maomé, mesmo sem termos realizado, ainda, profundas reflexões, foi uma disposição intencional de representar o Islamismo como uma "prática terrorista" que deve ser exterminada; e tudo isso acionado pelas charges, com seu poder persuasivo e mobilizador.

\section{0 interdito das imagens e a dupla infração}

Não se pode dimensionar o impacto das charges sem levar em consideração a profunda desconfiança de ordem religiosa e cultural que o Islamismo guarda em relação às imagens. Em seu domínio, é possível apenas observar a presença de uma arte geométrica, destituída de elementos figurativos, reforçando a impossibilidade de apreender o Sagrado através de imagens.

Figurar o divino, dar-lhe uma expressão visual, implicaria, fatalmente, cair em idolatria, condenável não somente no Islamismo, mas também nas duas outras religiões abraâmicas, Judaísmo e Cristianismo². Nestas, o interdito das imagens religiosas está claramente expresso no segundo mandamento da Lei Mosaica: “Não faça imagens de nenhuma coisa que há lá em cima no céu, ou aqui embaixo na terra, ou nas águas debaixo da terra. Não se ajoelhe diante de ídolos, nem os adore..." (Êxodo 20: 4-5). Já, o livro sagrado dos Muçulmanos não traz nenhuma condenação explícita às imagens. Isto só pode ser depreendido em raras passagens. Entretanto, como característica tradicional das religiões centradas no texto, Allah só pode se deixar aproximar pelo fiel, mediante o Corão. A experiência do Sagrado passa preferencialmente pelo exercício da razão mediante a palavra escrita. É a palavra, mediadora suprema, que fornece até mesmo o modelo arquitetônico não-icônico das Mesquitas, conforme lembra o historiador Alain de Besançon (2000, p.80).

As religiões centradas em textos, incluindo aqui o Islamismo, são espaços em que a primazia semiótica da palavra, modelo mais afeito à razão e de pouco apelo sensorial, contrasta com a ordem mágica das imagens de culto, típica de religiões pagãs romana, egípcia ou grega. Portanto, principalmente em sua circunscrição religiosa, os textos não devem ser pensados senão a partir das tensões que estabelecem com as imagens. A este respeito, é interessante retomar as relações que Vilém Flusser estabelece entre imagens e textos e seus desvios, a idolatria e a textolatria.

São (os textos) mediações tanto quanto o são as imagens. Seu propósito é mediar entre homem e imagens. Ocorre, porém, que os textos podem tapar as imagens que pretendem representar algo para o homem. Ele passa a ser incapaz de decifrar textos, não conseguindo reconstituir as imagens abstraídas. Passa a viver não mais para se servir dos textos, mas em função destes (2002, p.11).

A relação de complementaridade entre textos e imagens não deve ocultar suas tensões, sobreposições, e até mesmo mecanismos de anulação de uma linguagem pela outra, recorrentes, sobretudo, no campo da religião. Neste sentido, as charges de Maomé, representam uma dupla infração. A primeira é figurar algo circunscrito ao domínio do Sagrado ${ }^{3}$; a segunda é servir-se da imagem do Profeta para criticar ofensivamente o universo muçulmano.

\section{Iconoclasmos e sua moldura midiática}

A charge que figura Maomé e seu turbante em forma de bomba, além de associar diretamente o profeta muçulmano ao terrorismo, está aberta a outras interpretações semióticas. A bomba esférica preta com um pavio aceso nos remete a um evento futuro de explosão, como se operasse simbolicamente uma destruição do Islã através da síntese operada pela imagem de Maomé. A charge também permite uma outra leitura (além de outras possíveis) que responsabiliza a religião islâmica, representada pela figura de seu Profeta, pela eclosão de discórdias, tensões e conflitos recentes, opondo o Ocidente Cristão e o Oriente Islâmico.

O que chama atenção nesta charge, entretanto, é o prenúncio de destruição da própria imagem de Maomé, gesto iconoclasta ${ }^{4}$, por excelência. Os muçulmanos, além de ter que lidar com a intolerável imagetização de Maomé, precisariam ainda absorver a iminência de quebra e violência perpetrada contra a mesma imagem.

Como gesto iconoclasta, a charge filia-se perfeitamente a uma tradição protestante de valoração das imagens religiosas, sendo oportuno lembrar que a Dinamarca é um país de maioria luterana. Ainda que as motivações religiosas protestantes não sejam tão determinantes na vida cotidiana da população escandinava, suas matrizes culturais protestantes dão novas cores a este episódio recente.

De fato, a Reforma religiosa do século XVI, no que toca 
ao problema das imagens religiosas, foi um evento eminentemente iconoclasta. Reformadores como Lutero, Calvino e Zuínglio recapitulam, de alguma maneira, o Judaísmo e o Islamismo, ao defender o primado da palavra como meio de acesso ao Sagrado. Embora Lutero tivesse restrições aos iconoclastas, defendendo somente o abandono do culto aos ícones, ele acaba por reiterar a substituição de seu poder pelo da palavra. "O reino de Deus é um reino do ouvir, não do ver" (apud. Belting: 1994, p. 465).

A quebra de imagens foi ruidosa nos desdobramentos da Reforma na Suíça. O historiador da arte alemão, Hans Belting (1994, p. 461), comenta que em Genebra as massas não se contentavam com a simples remoção das imagens. Muitos ícones eram deixados em seus altares de origem, mas tinham seus membros quebrados, a fim de que ficasse comprovada a sua falta de poder. "Zombar das imagens era às vezes mais importante do que a sua remoção" 5 , afirma Belting (1994, p.461). Mais do que pela reprovação teológica dos ícones, os eventos iconoclastas eram motivados pelos vínculos simbólicos entre os ícones e a igreja romana.

Beneficiando-se da revolução operada pela imprensa de Gutenberg, os reformadores despejaram ao debate público uma avalanche de textos panfletários condenando as práticas do Vaticano, como a venda de indulgências. Muitos destes panfletos eram ilustrados com charges, associando o Papa à imagem de um asno, demônio ou anticristo, como o fazem alguns textos assinados por Lutero e Melanchton, como nos mostra Fritz Saxl (1989). Era necessário, além do confronto teológico expresso textualmente, destruir o outro simbolicamente através da imagem.

As charges de Maomé sinalizam esta função de destituição simbólica do poder do outro. Elas demarcam claramente a oposição de universos simbólicos que se polarizam e se tensionam: um Ocidente iconoclasta, adequadamente sintetizado no fundamentalismo evangélico de George W. Bush, e um Oriente iconofóbico, que se assemelham na sua eterna inquietação em relação às imagens, mas que se digladiam em batalhas midiáticas para a destruição das imagens do outro. Sem dúvida, o estopim, o ataque à imagem-símbolo das torres gêmeas, inscrevera-se como um gesto eminentemente iconoclasta.

Estas formas de criação de tensões, polarizações, são descritas dentro da dinâmica dos textos ${ }^{6}$ culturais, pelos semioticistas Lotman, Ivanov, Uspenskii, Piatigorskii e Toporov, como expressões da demarcação de limites semióticos entre os espaços da "cultura" e da "nãocultura"7. Assim, deve-se levar em conta que, a esfera da cultura, do ponto de vista do indivíduo nela inserido, com a delimitação de seu universo simbólico, se afirma e se nutre a partir da constituição e recriação constante (em função de um dinamismo dialógico) de um universo simbólico que lhe é externo, denominado aqui "nãocultura", o que na verdade implica uma reconstrução ininterrupta da alteridade. Pelo fato de a cultura não viver somente da oposição das esferas interna e externa, mas também movimentar-se entre elas, a cultura não somente luta contra o "caos" externo, mas dele também necessita; ela não somente o destrói, como continuamente o cria.

(...) Por isso, pode-se dizer que a cada tipo de cultura corresponde o seu tipo de "caos" que de maneira alguma é primário, uniforme e sempre igual a si mesmo, mas representa uma criação humana tão ativa quanto a esfera da organização cultural. Cada tipo de cultura historicamente dado tem o seu próprio, e somente a ele peculiar, tipo de não-cultura (apud. Machado: 2003, p.101).

As polarizações não devem ser confundidas com mecanismos de redução da complexidade cultural a dicotomias simplificadoras. A dinâmica da "Cultura" e "nãocultura" não prescinde da diversidade e dos paradoxos existentes dentro de um mesmo sistema, mas, em um nível primário, ajuda a descrever os movimentos dinâmicos dos sistemas simbólicos na cultura.

Certamente, a recriação destes novos espaços da "nãocultura" teve como elemento catalisador uma série de gestos iconoclastas, entre os quais as charges de Maomé, tendo sua visibilidade exponencializada pelos meios de comunicação de massa. Em um mundo onde a existência social é condicionada e legitimada pelo espetáculo, as imagens midiáticas são cada vez mais convocadas a ser lugar da destruição simbólica do outro. Desta forma, todos os conflitos e tensões se imagetizam e, portanto, se inscrevem como novas formas de agressão simbólica. Desde o ataque ao World Trade Center, em 11 de setembro de 2001, passando pela derrubada da estátua de Saddam Hussein, sua posterior captura e condenação à forca, o que se evidencia são formas de um novo iconoclasmo midiático.

Se tomarmos como premissa o domínio dos simulacros, descrito por Jean Baudrillard (1991), todas as tensões passarão a convergir para o plano das imagens midiáticas. Assim, as charges de Maomé constituem-se apenas como um episódio em um processo contínuo de demarcações semióticas que, necessariamente, nos reservará futuros capítulos maAmEcos

\section{NOTAS}

* Este trabalho foi apresentado no NP Semiótica da Comunicação do XXX Congresso Brasileiro de Ciências da Comunicação (Intercom 2007)

\section{Ver <http://www.zone-h.org/en/index>.}

2 O Florescimento da iconografia no seio do cristianismo fez-se acompanhar de um acalorado debate teológico em torno do estatuto das imagens reli-giosas, cujos picos são o iconoclasmo bizantino superado com o Segundo Concílio de Nicéia, no séc. VIII, e a Reforma Protestante do séc. XVI.

3 Mesmo que se considere somente Allah como figura 
divina, Maomé insere-se no espaço do Sagrado por ser considerado o principal profeta no Isla-mismo. As charges, portanto, não foram repro-duzidas neste artigo, por razão de seu caráter ofensivo, bem como para evitar eventuais cons-trangimentos aos autores do artigo e à editora da revista.

4 A palavra iconoclasta tem origem na justaposição dos termos gregos "eikonos" e "klastes" e significa literalmente "aquele que quebra imagens".

5 Tradução feita pelos autores a partir da seguinte passagem: "The mocking of images was sometimes more important than their removal".

6 O conceito de texto aqui não se restringe aos textos verbais, mas deve ser entendido como resultado de associações sígnicas. Sobre a elucidação deste conceito, remetemos o leitor ao livro "O Animal que Parou os Relógios", de Norval Baitello Júnior.

7 Usamos aspas para destacar que as noções de cultura e não-cultura são aqui descritas de um ponto de vista semiótico, levando-se em consi-deração a perspectiva do participante de uma dada cultura. Não é nossa intenção aqui operar-mos com um conceito antropológico, segundo o qual a noção de não-cultura é simplesmente inconcebível.

\section{REFERÊNCIAS}

A Bíblia Sagrada: nova tradução na linguagem de hoje. São Paulo: Sociedade Bíblica do Brasil, 1998.

BAITELLO JR., Norval. O animal que parou os relógios. São Paulo: Annablume, 1997.

BARONAS, Roberto Leiser. Caricaturas e charges sobre Maomé: derrisão, memória e resistência(s). Disponível em: <http://www3.unisul.br/paginas/ensino/ pos/linguagem/gt_andis/011;htm>. Acesso em 19/ 05/2007.

BAUDRILLARD, Jean. Simulacros e simulação. Lisboa: Relógio D'água, 1991.

BELTING, Hans. Likeness and presence: a history of the image before the era of art. Chicago: The University of Chicago Press, 1994.

BESANÇON, Alain. The forbidden image: an intellectual history of iconoclasm. Chicago: The University of Chicago Press, 2000.

CARVALHO, Lejeune Mato Grosso de. A polêmica das charges contra Maomé. 23/02/2006. Disponível em: <http://www.vermelho.org.br/diario/2006/0223/ lejeune_0223.html>. Acesso em 19/05/2007.
DIAZ, Ricardo. Charges da discórdia: a liberdade de expressão tropeçando na ética. 20.02.2006. Disponível em: http://www.duplipensar.net/dossies/crise-dascharges-de-maome/charges-da-discordia-liberdadede-expressao-tropecando-na-etica.html >. Acesso em 19/05/2007.

ECO, Umberto. Los marcos de la 'libertad' cómica. In: ECO, Umberto; et.al. Carnaval! México: Fondo de Cultura Económica, 1989, pp. 9-20.

FLUSSER, Vilém. Filosofia da caixa preta: ensaios para uma futura filosofia da fotografia. Rio de Janeiro: Relume Dumará, 2002.

MACHADO, Irene. Escola de semiótica: a experiência de Tartu-Moscou para o estudo da cultura. Cotia: Ateliê Editorial, 2003.

MAESTRI, Mário; MATOS, Marconi de. Charges de Maomé: há algo de muito podre no reino da Dinamarca. Fevereiro de 2006. Disponível em: http:// www.consciencia.net/2006/0219-maestri1.html>. Acesso em 19/05/2007.

MIANI, Rozinaldo Antonio. As transformações no mundo do trabalho na década de 1990: o olhar atento da charge na imprensa do Sindicato dos Metalúrgicos do ABC paulista. Assis, SP: Unesp/Campus Assis, 2005. Tese (Doutorado em História). Faculdade de Ciências e Letras de Assis, Universidade Estadual Paulista, Assis, 2005.

A utilização da charge na imprensa sindical na década de 80 e sua influência política e ideológica. São Paulo: ECA/USP, 2000. Dissertação (Mestrado em Ciências da Comunicação). Escola de Comunicações e Artes, Universidade de São Paulo, São Paulo, 2000.

SAXL, Fritz. La vida de las imágenes. Madrid: Alianza Editorial, 1989.

www.casadojornalista.org 